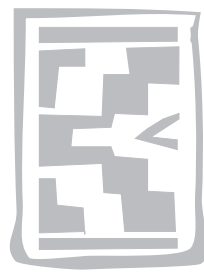

\title{
Claviceps cyperi, a new cause of severe ergotism in dairy cattle consuming maize silage and teff hay contaminated with ergotised Cyperus esculentus (nut sedge) on the Highveld of South Africa
}

\author{
T.W. NAUDÈ ${ }^{1}$, C.J. BOTHA², J.H. VORSTER ${ }^{3}$, C. ROUX ${ }^{4}$, E.J. VAN DER LINDE ${ }^{4}$, \\ S.I. VAN DER WALT ${ }^{5}$, G.E. ROTTINGHAUS ${ }^{6}$, L. VAN JAARSVELD ${ }^{7}$ and A.N. LAWRENCE 8
}

\begin{abstract}
NAUDÉ, T.W., BOTHA, C.J., VORSTER, J.H., ROUX, C., VAN DER LINDE, E.J., VAN DER WALT, S.I., ROTTINGHAUS, G.E., VAN JAARSVELD, L. \& LAWRENCE, A.N. 2005. Claviceps cyperi, a new cause of severe ergotism in dairy cattle consuming maize silage and teff hay contaminated with ergotised Cyperus esculentus (nut sedge) on the Highveld of South Africa. Onderstepoort Journal of Veterinary Research, 72:23-37

During December/January 1996/97 typical summer syndrome (hyperthermia and a $30 \%$ drop in milk yield) occurred in succession in two Holstein dairy herds $(n=240$ and $n=150$ milking cows, respectively) on the South African Highveld. These farms are situated in the midst of the prime maize and dairy farming areas of South Africa where this condition had never been diagnosed before.

The individual components of the concentrate on both farms were negative for ergot alkaloids. Endophytic fungi and/or ergot infestation of teff and other grasses fed to the cows were then suspected of being involved, but neither endophytes nor ergot alkaloids could be implicated from these sources.

By measuring the serum prolactin levels of groups of sheep $(n=5)$ fed the first farm's total mixed ration (TMR) or its three individual fibre components for a period of 11 days, the source of the ergot alkaloids was identified. A statistically significant decrease in the level of this hormone occurred only in the group on maize silage (which constituted $28 \%$ on dry matter base of the TMR). The involvement of the maize silage was further chemically confirmed by the high levels of total ergot alkaloids, predominantly ergocryptine, found by LC-MS in the silage as well as in the TMR (115-975 ppb and 65-300 ppb, respectively). The ergot alkaloid content (mainly ergocryptine) of the maize silage on the second affected farm was $875 \mathrm{ppb}$. Withdrawal of contaminated silage resulted in gradual recovery of stock on both farms.

Nut sedge (Cyperus esculentus and Cyperus rotundus of the family Cyperaceae) has a world-wide distribution and is a common weed in annual crops, and can be parasitized by Claviceps cyperi. Careful examination of the maize silage from both farms revealed that it was heavily contaminated
\end{abstract}

1 Division of Toxicology, ARC-Onderstepoort Veterinary Institute, Private Bag X05, Onderstepoort, 0110 South Africa

Present address: Section of Toxicology, Department of Paraclinical Sciences, Faculty for Veterinary Science, University of Pretoria, Private Bag X04, Onderstepoort, 0110 South Africa. E-mail: theuns.naude@up.ac.za

2 Section of Toxicology, Department of Paraclinical Sciences, Faculty for Veterinary Science, University of Pretoria, Private Bag X04, Onderstepoort, 0110 South Africa

3 Division of Pathology, ARC-Onderstepoort Veterinary Institute, Private Bag X05, Onderstepoort, 0110 South Africa
4 Mycology Unit, Division of Biosystematics, ARC-Plant Protection Research Institute, Queenswood, Pretoria, 0121 South Africa

5 ARC-Animal Improvement Institute, Private Bag X2, Irene, Pretoria, 0062 South Africa

6 Veterinary Medical Diagnostic Laboratory, University of Missouri, Columbia, MO 65211, USA

7 Private practitioner, Balfour, Mpumalanga, South Africa

8 Farmer, Greylingstad, Mpumalanga, South Africa

Accepted for publication 9 June 2004-Editor 
with nut sedge and that it contained minute sclerotia, identified as those of Claviceps cyperi, originating from the latter. Nut sedge was abundant on both farms and it is believed that late seasonal rain had resulted in mature, heavily ergotised nut sedge being cut with the silage. Claviceps cyperi sclerotia, collected on the affected fields in the following autumn contained 3 600-4 $000 \mathrm{ppm}$ ergocryptine. That the dominant alkaloid produced by this particular fungus was indeed ergocryptine, was confirmed by negative ion chemical ionization MS/MS.

In one further outbreak in another Holstein herd, teff hay contaminated with ergotised nut sedge and containing $1200 \mathrm{ppb}$ alkaloids, was incriminated as the cause of the condition.

This is the first report of bovine ergotism not associated with the Poaceae infected with Claviceps purpureum or endophytes but with the family Cyperaceae and this particular fungal phytopathogen.

Keywords: Claviceps cyperi, Cyperus esculentus, dairy cattle, ergotism

\section{INTRODUCTION}

\section{Ergot alkaloid chemistry and pathophysiology}

Chemically two types of ergot alkaloids are recognised (Garner, Rottinghaus, Cornell \& Testereci 1993) both basically consisting of d-lysergic acid with an amide binding at C8: ergoclavines (simple lysergic acid amides, e.g. ergonovine) and ergopeptines (with three amino acids in a cyclol ring structure, e.g. ergotamine [Fig. 1]). All these alkaloids may induce problems in animal production and are produced by fungi of the Clavicipitaceae infecting members of the Poaceae (cereals and grasses). The Claviceps tribe, of which Claviceps purpurea is a prime example, infects the florets of various cereals and grasses producing overwintering sclerotia (ergots) in the maturing stages of the plants. These contain highly toxic levels of especially ergopeptine alkaloids.

The Balansiae tribe, on the other hand, are endophytic (intercellular) fungi rendering the grass itself toxic due to all of these alkaloids. Of these $\mathrm{NeO}$ - typhodium (= Acremonium) coenophialum (MorganJones \& Gams) Glenn, C.W. Bacon \& Hanlin, infecting tall fescue grass (Festuca elatior L.) and producing primarily ergovaline, is the most important example of veterinary significance and the cause of the "fescue foot" syndrome (Bacon, Lyons, Porter \& Robbins 1986; Cheek, 1998).

The mechanisms of action of ergot alkaloids are varied and complex-some are completely unrelated, and some are even mutually antagonistic. They appear to result from their action as partial agonists or antagonists at $\alpha$-adrenergic, dopaminergic and tryptaminergic receptors. The ergopeptine alkaloids cause prolonged constriction of both arteries and veins peripherally by $\alpha$-adrenergic blockade which is more pronounced in post capillary than precapillary vessels. In addition, it can also damage the capillary endothelium with consequent development of gangrene (Hoffman \& Lefkovitz 1996; Peroutka 1996). The dopamine agonist action directly activates lactotrope $D_{2}$-dopamine receptors leading to inhibition of spontaneous and $\mathrm{TRH}$-induced release<smiles>CN1C[C@H](C(=O)O)C=C2c3cccc4[nH]cc(c34)C[C@H]21</smiles>

d-Lysergic acid

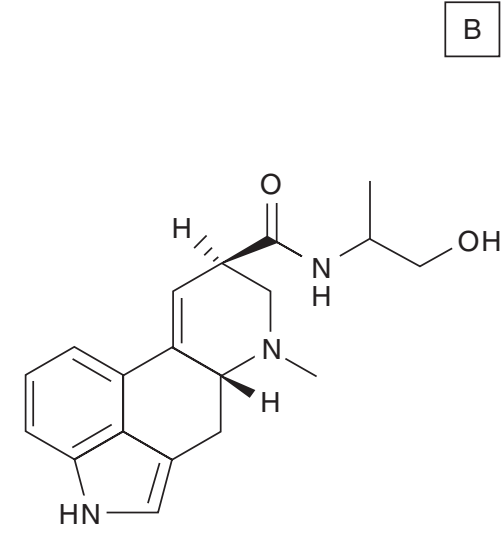

Ergonovine

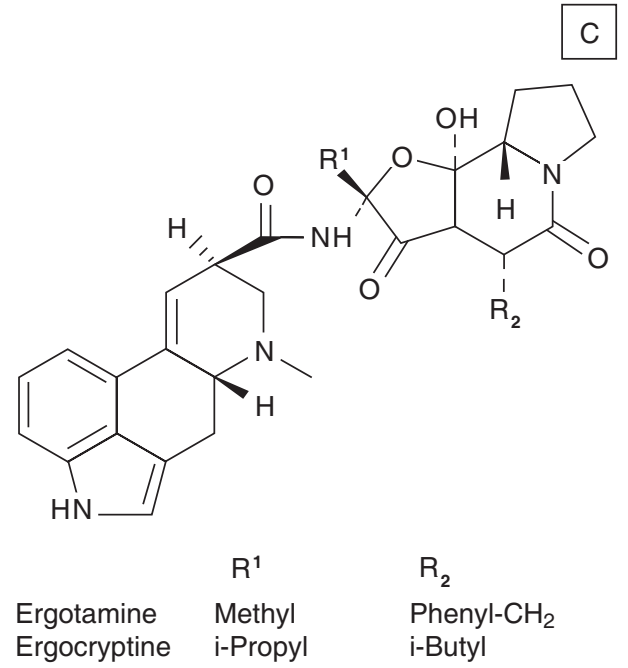

FIG. 1 The structures of (A) d-lysergic acid (B) ergonovine, a typical amide of the latter and (C) ergotamine and ergocryptine, typical cyclol ergopeptine alkaloids 
of prolactin (Ascoli \& Segaloff 1996) with consequently profound effects on lactation and reproduction.

In "summer syndrome" of cattle hyperpyrexia (due to cutaneous vasoconstriction and thus inability of animals to dissipate heat) and a precipitous drop in milk production occurs particularly in high producing dairy cows.

\section{Ergotism in South Africa}

This has only once been reported in the winter rainfall area of South Africa (Schneider, Miles, Garthwaite,Van Halderen, Wessels \& Lategan 1996) and resulted from Claviceps purpurea sclerotia originating from annual rye grass (Lolium hybrids) growing as weeds in barley lands. The ergots were concentrated in barley screenings and were inadvertently incorporated in a commercial dairy concentrate eventually affecting some 3000 cows. The signs were typically those of summer syndrome and calves that had been exposed to high doses of the infected material developed the gangrenous form of ergotism. The latter form of ergotism has also recently been diagnosed in South Africa (Botha, Naudé, Moroe \& Rottinghaus 2004).

\section{Highveld ergotism}

The central plateau grass veld of South Africa occurring at an altitude of ca $1000 \mathrm{~m}$ above sea level and having a relatively high annual rainfall, is known as the Highveld and is the prime maize and dairy area of the country. It is also relatively free from the more serious tick-borne diseases and plant poisonings of cattle. Maize silage is regarded as a safe feed and is extensively produced and utilized in both dairy and feedlot farming. Apart from the transient and temporary deleterious effects of mouldy maize silage (mainly related to unpalatability) no other frank toxicity has been recorded in South Africa. Ergotism in any form had never been reported from this area.

During mid-summer 1996/97 three outbreaks of typical summer syndrome in dairy cows were clinically diagnosed and confirmed chemically in the area and the sequence of events is described as they chronologically occurred. The first was at Greylingstad (28 $52^{\prime \prime}$ E; $\left.26^{\circ} 47^{\prime \prime} \mathrm{S}\right)$ and will be designated as the first outbreak and was investigated on 20 December 1996 (day 0 of this outbreak).

The next was near Memel (2729" S; $29^{\circ} 47^{\prime \prime}$ E), designated as the second outbreak, which was investigated 8 weeks after the first outbreak. The third was near Vrede (29॰06" E; $\left.27^{\circ} 33^{\prime \prime}\right)$, designated as the third outbreak, and was investigated 3 months after the initial outbreak.

All the farms are situated within a radius of $c a 70 \mathrm{~km}$ of each other with the first ca $140 \mathrm{~km}$ from the ARCOnderstepoort Veterinary Institute (OVI) from where the investigation was instigated and co-ordinated by the diagnostic unit of the Division of Toxicology.

\section{MATERIALS AND METHODS}

These varied from farm to farm. The detailed techniques undertaken during the first outbreak are described, whereas those that were used during the other two outbreaks were merely confirmatory and basically only of a chemical nature unless otherwise stated.

\section{Clinical pathology}

Venous blood was collected in heparinized and non-heparinized tubes under vacuum from ten clinically affected cows in all three outbreaks for routine chemical pathological analyses. These included the haematocrit, haemoglobin concentration, serum $\gamma$ GT-, AST- and CK-activities, and urea, creatinine, sodium, potassium, calcium, phosphate and copper values.

\section{Mycology and endophyte examination}

The first phase of this investigation consisted of the examination of pasture grasses for possible endophytes; this was done only during the first outbreak. It was undertaken at the OVI and the Stellenbosch Regional Veterinary Laboratory on fresh Eragrostis tef and Eragrostis curvula as well as the grasses of other species in the holding camps. For this purpose sections of the plants were stained for subsequent light microscopy using the Rose-Bengal staining technique of Saha, Jackson \& Johnson-Cicalese (1988).

Material was also despatched to the Toxinology and Food Safety Research Group of the Ruakura Agricultural Research Station, Hamilton, New Zealand where it was examined by ELISA for the presence of toxigenic endophytes and related ergot alkaloids by the technique of Garthwaite, Sprosen, Briggs, Collin \& Towers (1994).

The second phase consisted of mycologically confirming the identity of the causative organism on nut sedge (vide infra). 


\section{Necropsy and histopathology}

No mortalities occurred and only one examination was undertaken on one badly affected Holstein cow in the first outbreak that had markedly lost condition. The animal was slaughtered at an abattoir on day 0 and specimens of all major organs were collected in buffered $10 \%$ formalin, processed according to standard procedures and stained with haematoxylin and eosin for histopathological examination.

\section{Chemical analyses}

Analysis for gossypol was done at the Division of Toxicology of the OVI according to the method of Pons \& Hoffpauiar (1957).

Analyses for ergot alkaloids were initially performed at Meadows Cape in Paarl, Western Cape Province, South Africa where extractions were done according to the technique of Scott, Lombaert, Pellaers, Bachler \& Lappi (1992) and the high performance liquid chromatography (HPLC) by the method of Rottinghaus, Schultz, Ross \& Hill (1993). A Waters 600 HPLC system with a 470 Fluorescence Detector and a 717 Auto Sampler and a Phenomex Luna C18 column $(0.15 \times 4.6 \mathrm{~m})$ were used.

Subsequently, milled feed or basic chloroform extracts of it were sent by courier to the Veterinary Medical Diagnostic Laboratory, University of Missouri, Columbia, USA for ergopeptine analysis by the HPLC technique described by Rottinghaus et al. (1993). Samples were extracted with alkaline chloroform, filtered and applied to Ergosil cleanup columns (Analtech, Newark, DE). Following elution of pigments with acetone:chloroform (8:2), the ergopeptine alkaloids were eluted with methanol and analysed by HPLC with fluorescence detection. Confirmation of ergopeptine alkaloids was obtained by treatment of the sample with $0.2 \%$ acetic acid and re-examination by HPLC for the -inine isomers. The HPLC system consisted of a Perkin Elmer LC 250 pump, a Perkin Elmer ISS200 autosampler, with detection on a Hitachi F-1200 fluorescence detector. A Phenomenex Luna C18 column (0.15 x $4.6 \mathrm{~m}$ ) was used with a mobile phase of acetonitrile: water (35:65) with $200 \mathrm{mg}$ ammonium carbonate per liter.

The identity of the $\alpha$-ergocryptine was unequivocally confirmed by further silica gel/organic binder cleanup and tandem mass spectroscopy (Finnigan/MAT TSQ 70 Tandem Mass Spectrometer [MS/MS]) at the US Department of Agriculture, National Veter- inary Services Laboratories, Ames, lowa, USA, according to the technique of Rottinghaus et al. (1993). Briefly, chloroform extracts were processed through silica gel/organic binder cleanup columns described above. A portion of the extract was applied to a direct exposure probe, the solvent was allowed to evaporate and the probe was inserted into the mass spectrometer source. The MS/MS was operated in the negative chemical ionization mode with methane as the reagent gas and argon as the collision gas. Daughter ions were collected for the ergocryptine parent ion $\mathrm{m} / \mathrm{Z}$ 308. Typical daughter spectra were obtained with base peak m/Z 209 as described by Plattner, Yates \& Porter (1983) and Rottinghaus et al. (1993).

\section{Prolactin (PRL) determination}

This was only done during the first outbreak. It consisted of a trial using sheep in an attempt to determine the source of the ergot. Five groups $(n=5)$ of randomly selected, ca 1-year-old Mutton Merino ewes were given an exclusive diet of the suspect feed components of the milk cows for 11 days. The groups received the total mixed ration (TMR), teff hay (Eragrostis tef), Eragrostis curvula hay, a mixture of grasses growing in the holding pens of the cows or the maize silage used on the farm. All rations were fed ad lib and the animals had free access to drinking water. Blood was collected by jugular venipuncture on days $0,4,7$ and 11 and the serum separated by centrifugation at $4{ }^{\circ} \mathrm{C}$ and stored at $-20^{\circ} \mathrm{C}$ for subsequent examination.

Blood was similarly collected from the median caudal (coxygeal) vein, ca $4 \mathrm{~h}$ after milking from 20 cows with the most pronounced clinical signs of hyperthermia on day 1 of this outbreak $(21 / 12 / 1996)$ and again on day 29 (18/1/1997) from 19 animals with the most dramatic drop in milk production. The serum was stored at $-20^{\circ} \mathrm{C}$ until analyzed. To compare the PRL levels to those of unexposed animals, a set of determinations was also done on the serum of a group of normal Holstein cows $(n=8)$ from the dairy herd of the ARC-Animal Nutrition and Animal Products Institute, Irene. The animals were fed a similar diet and were at approximately the same stage of lactation. Prolactin concentrations were determined by a double antibody radio-immunoassay (Hunter \& Greenwood 1964) as optimized by Van Zyl (1988). The antigen and antiserum were supplied by the National Institute of Arthritis, Diabetes and Digestive and Kidney Diseases (NIADDK), Maryland, USA. 
The radioligand assay data were calculated with a computer programme based on the (Logit-Log) theory of Rodbard \& Frazier (1975). The correlation coefficient of the standard curve was always greater than -0.99 . The results were statistically analysed by multiple regression analysis with the aid of STATISTICA for Windows, release 5.1 (F) of 1997.

\section{HISTORY AND RESULTS OF INVESTIGATION OF THE THREE OUTBREAKS}

\section{FIRST OUTBREAK}

This occurred on a long established, well-managed dairy farm near Greylingstad with a 240 Holstein cow herd (210 in milk and 500 head in toto) in mid summer 1996. Typical summer syndrome, viz. hyperthermia, open-mouthed breathing (Fig. 2), shade seeking (even on overcast days), lying down in damp, muddy areas, wading into a dam up to the neck, even at night (Fig. 3) and a 33\% drop in milk production had been occurring since the beginning of December. These signs were only evident in cows in milk of which the majority were involved. An increasing incidence of infertility became apparent. It subsequently transpired that the problem had followed the opening and use of a new bunker of maize silage.

Milk cows were on a total mixed ration (TMR) and had access to small holding camps with limited natural grasses mainly kikuyu (Pennisetum clandestinum) and Cynodon dactylon and smaller numbers of Eleusine indica, Eragrostis plana and Bromus catharticus.

The TMR consisted of the following:

$20 \mathrm{~kg}$ (dry matter base) maize silage (of the previous season)

\section{$1.5 \mathrm{~kg}$ teff or Eragrostis curvula hay}

$4.5 \mathrm{~kg}$ soda maize ( $\mathrm{NaOH}$-treated maize)

$3 \mathrm{~kg}$ lucerne hay

$1.5 \mathrm{~kg}$ hominy chop (maize bran and germ)

$2.0 \mathrm{~kg}$ cotton seed

$2.5 \mathrm{~kg}$ molasses

$3.8 \mathrm{~kg}$ high protein concentrate (HPC)

$51 \%$ soyabean oil cake

$25 \%$ cotton oil cake

Fish meal, gluten, molasses urea, salt and minerals.

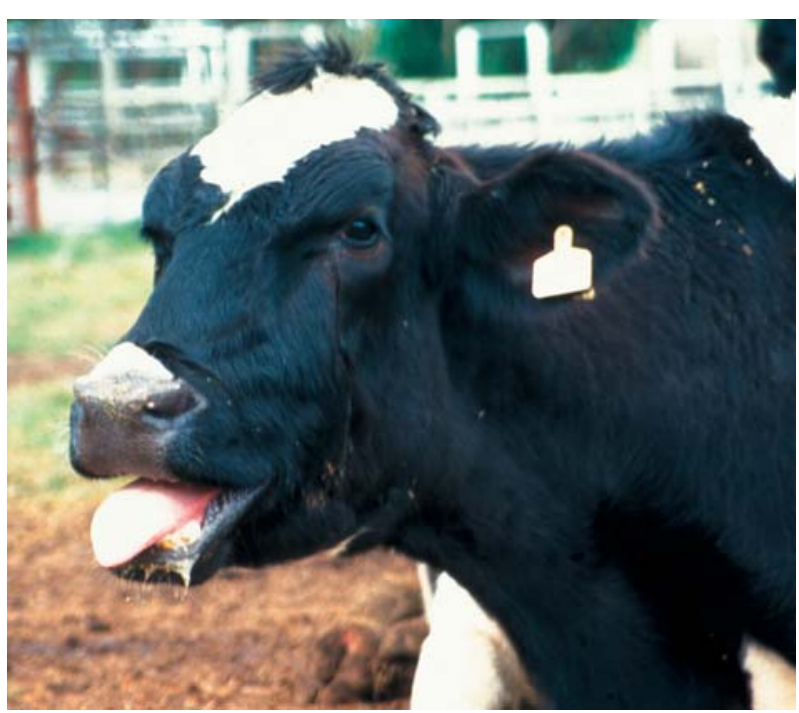

FIG. 2 Open-mouthed breathing as seen in the "summer syndrome"

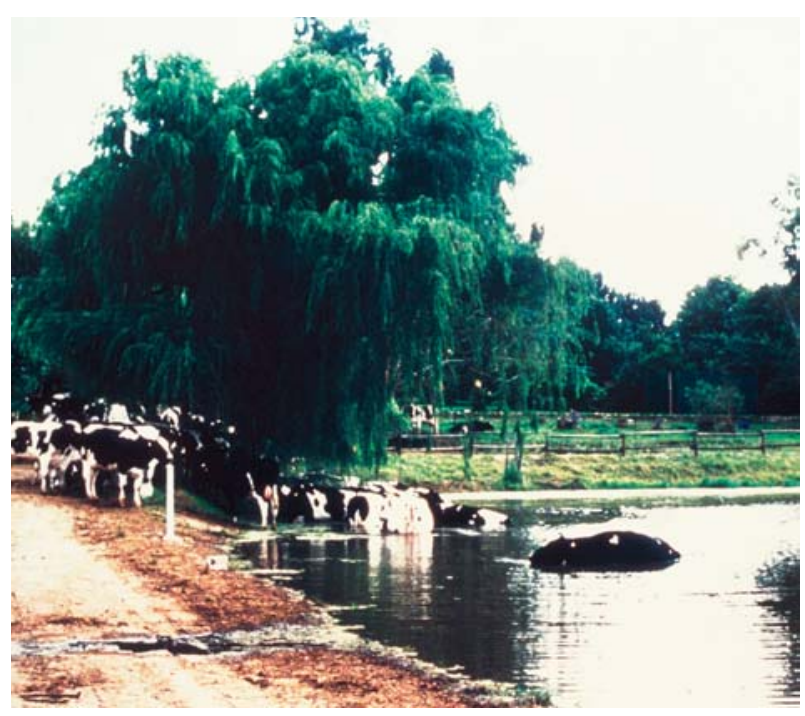

FIG. 3 Cows wading into a dam to cool off

The ration consisted of $52 \%$ maize silage as fed and this, the hay and soda maize originated from the farm. The other components and HPC were obtained from a local commercial feed company.

A tentative diagnosis of ergotism was made as there was no history of any other causative agents of hyperthermia such as haloginated salicylanilides or pentachlorophenol which uncouples oxidative phosphorilation (Osweiler, Carson, Buck \& Van Gelder 1985) being used. The gossypol content of the ration was considered but the most probable cause was thought to be ergotism and the source first suspected was the brought-in components 
such as the HPC. The possibility of ergotised or endophyte-infected grass also had to be considered.

\section{Results}

\section{Chemical pathological blood analyses}

These revealed no specific changes indicating any specific cause of the syndrome.

\section{Examination for ergotised or endophyte infected grass}

The only sclerotia found on members of the Poaceae on this farm were on natural paspalum (Paspalum dilatatum) grass growing in particularly the moister, shaded areas of the natural grazing.

As teff and E. curvula were specifically cultivated for and formed a significant ingredient of the cows' ration, these two grass species (despite the fact that they had never previously been implicated in endophytic ergotism) had to be considered. Endophytic hyphae were indeed present in these two grass species examined according to the technique of Saha et al. (1988) and our findings were confirmed by the Regional Veterinary Labotatory at Stellenbosch (A. van Halderen \& J. Wessels, personal communication 1997).

The Ruakura Agricultural Research Station, however, found the teff and Eragrostis curvula seed negative for Neotyphodium-like endophyte mycelium by ELISA and microscopy (Garthwaite 1997), and excluded lysergol-containing endophytic ergot alkaloids and paxilline (a precursor of the toxic lolitrems, a further indicator of toxic endophytes) by ELISA (Garthwaite et al. 1994) from all seed and vegetative material of teff and E. curvula submitted to them (I. Garthwaite \& C.C. Miles, Agresearch, Ruakura, New Zealand, personal communication 1997).

The holding camps' grasses, $P$. clandestinum, $C$. dactylon, E. indica, E. plana and B. catharticus were also examined locally for endophytes but with negative results.

\section{Gossypol analysis results}

Levels in the feed $(0.02-0.08 \%)$ and in the cotton seed $(0.8 \%$ free gossypol) were within normal limits.

\section{Ergot alkaloid analyses}

The maize, HPC, and all brought-in components of the ration were tested by both Meadows, Cape and the University of Misssouri with negative results. All except one of the grass specimens, including teff and E. curvula seed, were consistently devoid of any ergot alkaloids at both laboratories, the one exception being, at that stage inexplicable, a positive result, viz. a specimen of unsifted teff seed which Meadows, Cape found to have a strong peak consistent with ergocryptine. This was later confirmed by the University of Misssouri and quantified by HPLC to contain a total of $580 \mathrm{ppb}$ of ergocryptine.

Analyses of two batches of the TMR and dried silage sent in December 1996 and on 7/1/1997 to Paarl were negative for these alkaloids.

On day 55 (13 February1998) some 8 weeks after the condition was diagnosed clinically, no positive chemical results were yet available. However, the prolactin results, indicating that the silage was indeed the cause were available (vide infra) and this, in conjunction with the second outbreak (vide infra) in which the owner had already withdrawn the batch of silage that had twice been associated with the syndrome, lead to withdrawal of the silage from the cows' ration at this first outbreak.

The first positive analytical HPLC results were received on day 59 and these, together with subsequently data received from the University of Missouri on four batches of TMR and/or silage, are reflected in Table 1.

An example of a typical chromatogram of the alkaloids found on extraction of the samples by HPLC appears in Fig. 4.

Removal of the incriminated silage from the ration resulted in the gradual abatement of the clinical signs of intoxication and return of milk production to pre-exposure levels as reflected in Fig. 5. After the 2 months' exposure a definite reddish tinge to the hair of the black patches of the Holsteins was evident in a number of animals. Severe problems with infertility were still experienced for some months more and a number of animals had to be culled for this reason.

\section{Results of prolactin determinations}

The results of these tests only became available on day 52, 7 weeks after the initial clinical diagnosis of ergotism was made.

In the sheep trial a statistically significant drop in $\mathrm{PRL}$ level only occurred in the maize silage group (Fig. 6).

The PRL data of the Holstein cows are reflected in Table 2. 
TABLE 1 Results of chemical analyses of different batches of maize silage and TMR

\begin{tabular}{|l|l|l|}
\hline Date collected & Feed component & Ergot alkaloid level \\
\hline $7 / 1 / 1997$ & TMR & $\begin{array}{l}300 \mathrm{ppb} \text { ergot alkaloids: } \\
\text { Ergosine } 10 \mathrm{ppb} \\
\text { Ergocornine } 31 \mathrm{ppb} \\
\text { Ergocrystine } 33 \mathrm{ppb} \\
\text { Ergotamine } 34 \mathrm{ppb} \\
\text { Ergocryptine } 200 \mathrm{ppb} \\
\text { Ergocryptine } 530 \mathrm{ppb} \text { (other alkaloids negligible) }\end{array}$ \\
\hline $8 / 1 / 1997^{*}$ & Maize silage & $\begin{array}{l}30 \text { ppb ergocryptine } \\
50 \text { ppb ergocryptine }\end{array}$ \\
\hline $15 / 1 / 1997$ & TMR & Negative \\
\hline $21 / 1 / 1997$ & Maize silage & $\begin{array}{l}65 \mathrm{ppm} \text { ergocryptine } \\
235 \mathrm{ppb} \text { ergocryptine }\end{array}$ \\
\hline
\end{tabular}

* Chloroform extract

$\mathrm{TMR}=$ Total mixed ration

TABLE 2 Decrease in milk yield and serum prolactin concentration of affected and normal Holstein cows in the first outbreak

\begin{tabular}{|l|l|l|l|}
\hline Group & Date & $\begin{array}{l}\text { Average \% drop in milk } \\
\text { yield (range) }\end{array}$ & $\begin{array}{l}\text { Average serum prolactin } \\
\text { in ng/m } \ell \text { (range) }\end{array}$ \\
\hline Most severely clinically affected cows $(n=20)$ & Day 1 & $23.55(+10-72)$ & $0.804(0-1.28)$ \\
Cows with most severe drop in milk yield $(n=19)$ & Day 29 & $47.70(33-61)$ & $0.194(0-0.717)$ \\
Control group* $(n=7)$ & $3 / 2 / 1997$ & Not applicable & $2.096(1.1-4.45)$ \\
\hline
\end{tabular}

* The PRL values of an eighth cow were exceptionally high, possibly due to stress, and were not considered
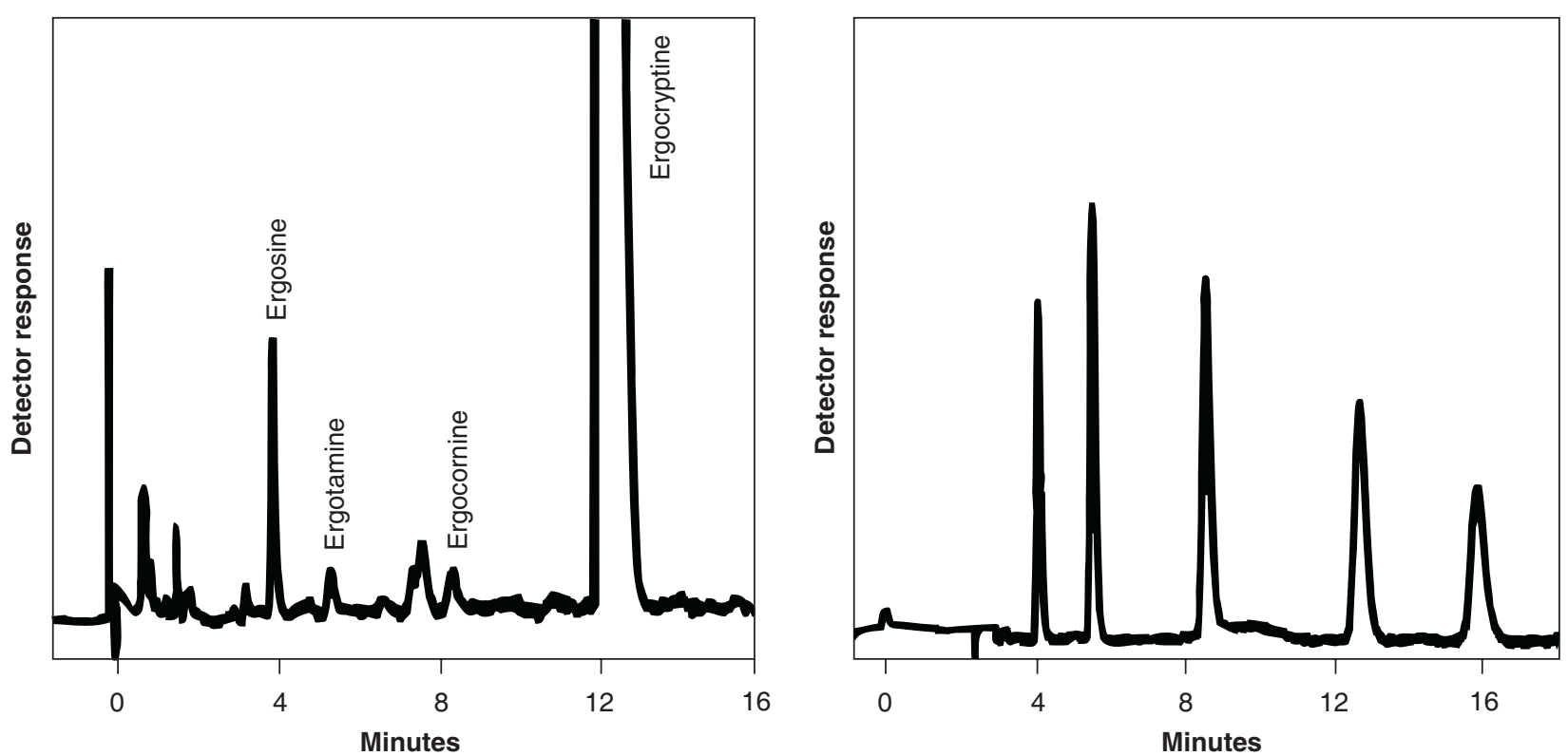

FIG. 4 A typical chromatograms of a Claviceps cyperi sclerotial extract containing the different ergopeptine alkaloids (left) in relation to that of a standard mixture (right). Note the exceptionally high ergocryptine peak 


\section{Determination of the causative fungus}

On day 59 the origin of the syndrome had been unequivocally determined as being the maize silage but no reason why it was positive was evident. Various weed grass spp growing in the maize fields in the year subsequent to the outbreak (1997) were inspected but no sclerotia could be found on any. The only ergotisation of maize ever described is that of Claviceps gigantea by Fuentes, de Lourdes de la Isla, Ullstrup \& Roderiquez in 1964. This fungus with its exceptionally large sclerotia on maize, had, however, never been seen in South Africa (Fucikovsky \& Moreno 1971).

The breakthrough occurred on day 59 when one of the authors (CR) remembered seeing ergotised nut sedge in the National Collection of Fungi of South Africa (PREM) in Pretoria. It became apparent that the nut sedges, Cyperus esculentus and Cyperus rotundus, which grow widely in maize fields in many countries, could be ergotised and that this had been described in South Africa by Loveless in 1967 (vide infra). Examination of specimens from this herbarium revealed the typical appearance of the small sclerotia. Subsequent careful scrutiny of the dried, sifted silage fed to the cows of the first outbreak (and which contained numerous yellow nut sedge seed heads), the typical sclerotia could be demonstrated (Fig. 7).

A few weeks later the yellow nut sedge weeds growing in the maize fields at all three sites of the outbreaks investigated, were starting to ripen and found to be infected with this particular fungus.

That this was indeed the cause of the syndrome was unequivocally proved by chemical determination of the ergot alkaloid levels in extracts of Claviceps cyperi sclerotia itself collected on sedges in the maize fields at the sites of the first two of the three outbreaks that had been investigated (Table 3)

TABLE 3 Ergocryptine levels of sclerotia collected in maize lands in 1997(note that levels are, in contrast to all the other chemical determinations mentioned, given in ppm and not ppb )

\begin{tabular}{|l|l|}
\hline Origin of Claviceps cyperi sclerotia & $\begin{array}{l}\text { Ergocryptine } \\
\text { levels (ppm) } \\
\text { in sclerotia }\end{array}$ \\
\hline First outbreak (Greylingstad) & 3600 \\
Second outbreak (Memel) & 4000 \\
Recovered from silage in second outbreak & 36.5 \\
Third outbreak (Vrede) & 4200 \\
\hline
\end{tabular}

\section{Botanical data on yellow nut sedge, Cyperus esculentus var. esculentus $\mathrm{L}$.}

Although both yellow and red nut sedge are subject to ergotisation, only yellow nut sedge was encountered on the farms involved in the three outbreaks.

Yellow nut sedge, (Fig. 8), is a fairly robust, stoliniferous, perennial herb growing up to $0.7 \mathrm{~m}$ high. The stolons are covered with scales and end in tubers. Annual spikelets are brown or rust-coloured (versus reddish in $C$. rotundus) and obtuse. The glumes are 2.2-2.6 $\mathrm{mm}$ long with raised reddish-brown nerves almost to the margin and with an uncoloured marginal border. The plant flowers from November to April (Retief \& Herman 1997).

Cyperus esculentus var. esculentus L. is widespread in Africa south of the Sahara, Iran, Yemen, Australia, Cambodia and Thailand where it can cause serious problems in especially annual crops when it grows as a weed in cultivated fields. Other varieties occur in the USA, Canada, South America and Europe where they can similarly cause problems (Holm, Plucknett, Pancho \& Herberger 1977).

\section{Mycological data on Claviceps cyperi}

\section{Historical review}

Claviceps nigricans was the first species of this genus described by Tulasne (1853) on members of the Cyperaceae, viz. on the genera Eleocharis and Scirpus. Doidge (1950) listed undetermined Claviceps spp. on both $C$. esculentus and $C$. rotundus. These had been collected at different localities in and around Pretoria during the period 1940-1944. Loveless, an expert on Claviceps, studied this material that had been deposited in the National Collection of Fungi, Pretoria and described a new species, Claviceps cyperi in 1967. It was subsequently never reported again until the outbreaks of bovine ergotism described here occurred in 1996/7.

\section{Life cycle}

Claviceps cyperi on yellow nut sedge (Cyperus esculentus) produces dark greyish-brown sclerotia which turn black when becoming older (Fig. 9). These sclerotia are similar to but much smaller than those formed by Claviceps purpurea on rye and other members of the Poaceae (Gramineae). Most are 6-8 $\mathrm{mm}$ long by $1 \mathrm{~mm}$ wide but specimens of up to $12 \mathrm{~mm}$ in length have also been found. They are generally straight but the longer sclerotia are slightly curved (Fig. 10) However, in addition, numerous 
T.W. NAUDÉ et al.

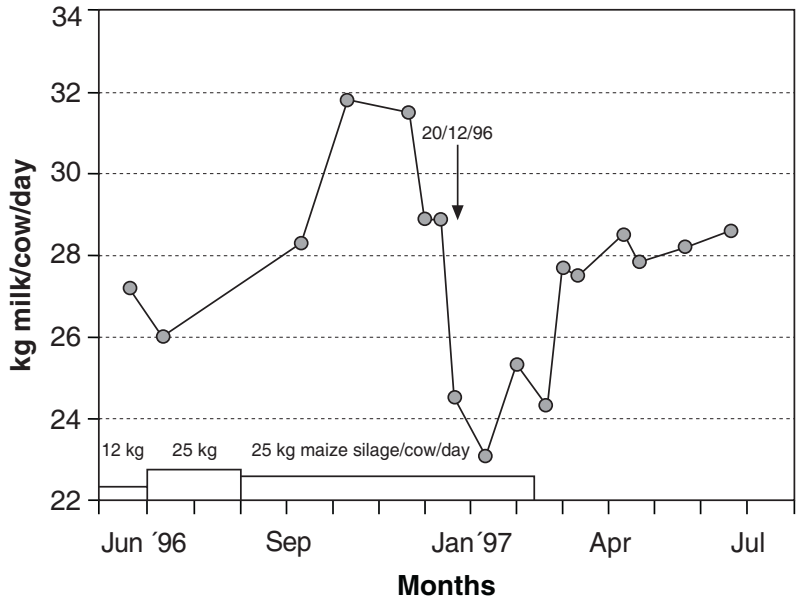

FIG. 5 Change in average milk yield in relation to feeding and withdrawal of incriminated maize silage in the first outbreak. The date of the first visit to the farm is indicated by the arrow

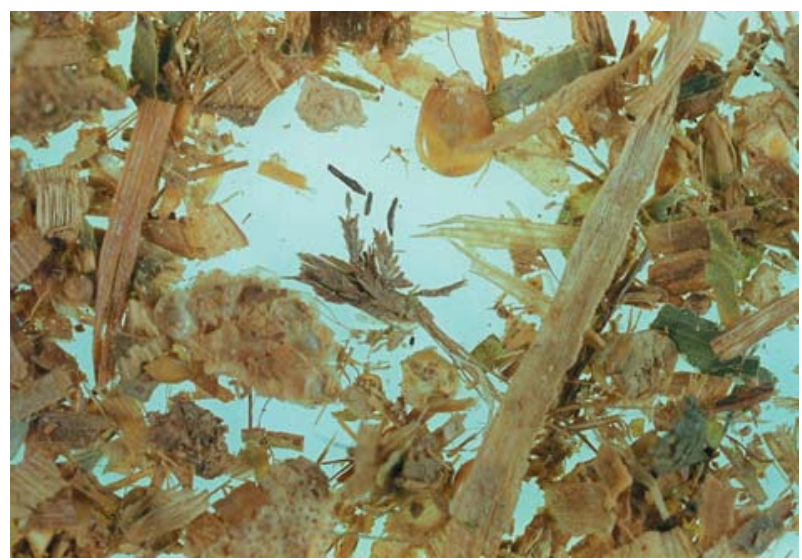

FIG. 7 The small, black, rod-like Claviceps cyperi sclerotia in dried maize silage (compare with Fig. 10)

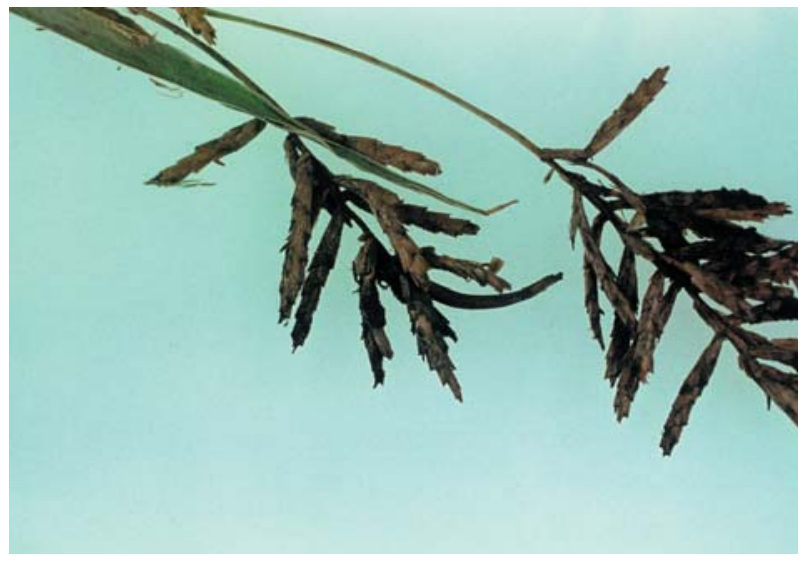

FIG. 9 A flower head of Cyperus esculentus showing a large, curved sclerotium of Claviceps cyperi

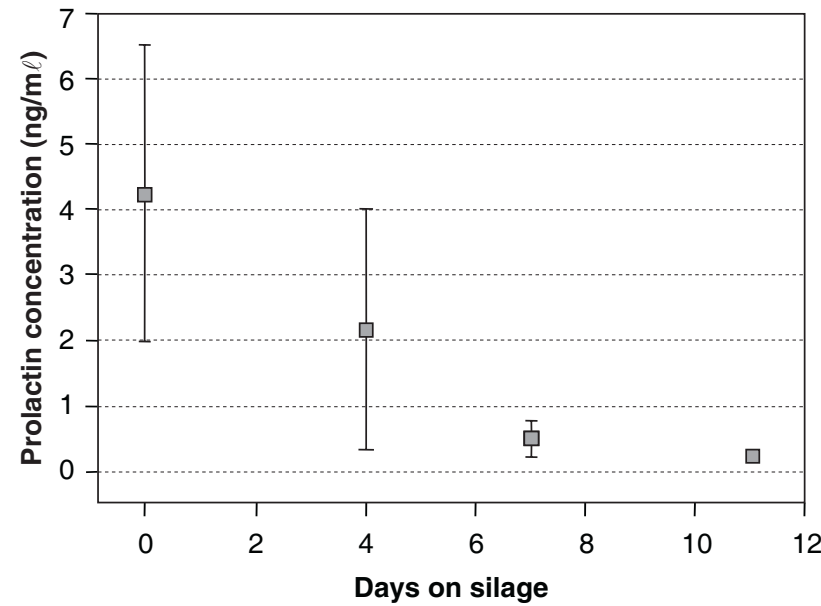

FIG. 6 Drop in serum prolactin concentration (mean " SD) in five sheep ewes fed the suspect maize silage in the first outbreak. The regression curve for the dependant variable PRL is described by $\mathrm{y}=3.870606-0.378650 \mathrm{x}$ days, $\mathrm{F}(1,18)=4.7684(P<0.04247)$, i.e. there is a $95.8 \%$ certainty that the slope of $y$ is not equal to zero

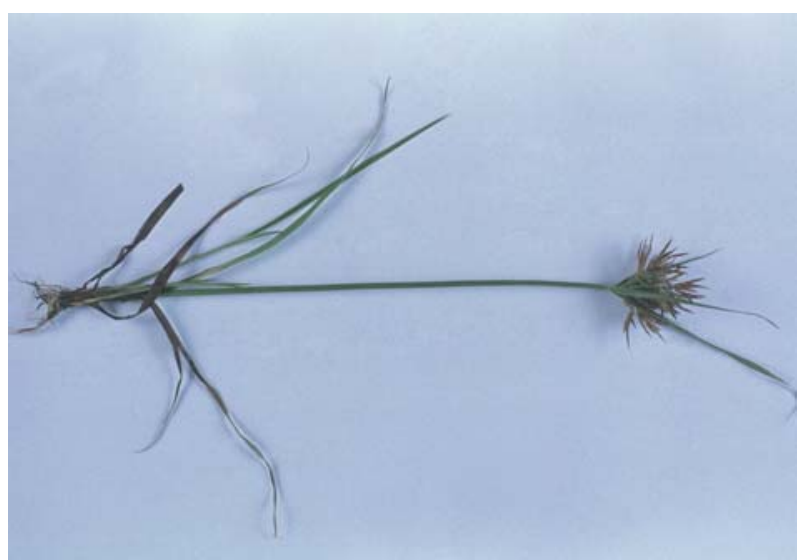

FIG. 8 Cyperus esculentus, yellow nut sedge

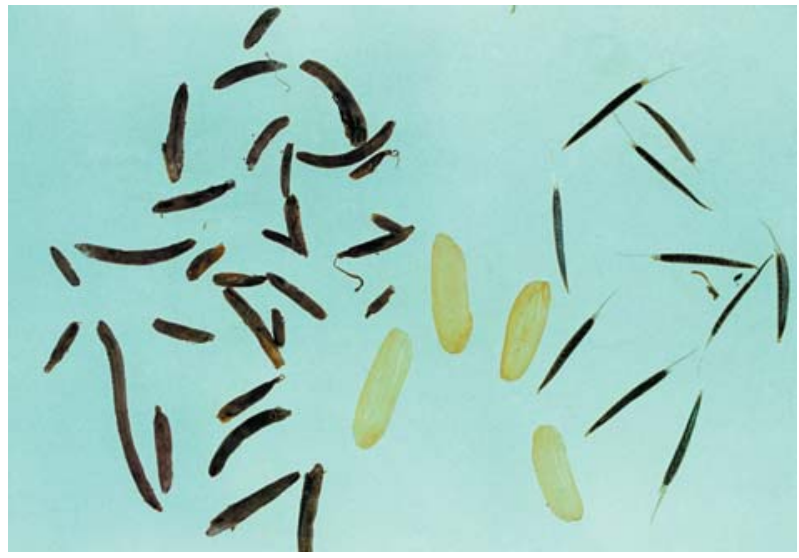

FIG. 10 Variation in size and shape of Claviceps cyperi sclerotia (left) in comparison with rice grains (centre) and Tagetes minuta, khaki bush, seeds (right) 
small, immature microsclerotia (3-5 mm long) may also be present.

Sclerotia are formed as the overwintering phase of the fungus when the nut sedge seed ripens and are able to survive extremely low temperatures. The extent of infection may vary from year to year, depending on temperature and rainfall. Sclerotia (which represent the sexual phase of the fungus) drop onto the ground where they have a resting or overwintering period. In the subsequent growth season, when conditions are favourable, they germinate to form stromata containing spores (ascospores) which are disseminated by rain, wind and insects, and infect young newly formed florets of the host plant. The spores then germinate and form a mycelial mass which, on its turn, gives rise to asexual conidia. This constitutes the start of the asexual or sphacelial stage of the fungus during which a sticky, sugary substance ("honeydew"), containing numerous conidia, is formed and continues to form during most of the summer. The "honey dew" is attractive to insects which then transmit the conidia to other florets infecting them. This generally coincides with the production of pollen by the nut sedge. The mycelial mass eventually forms the "sphacelium" which replaces the ovule of the floret and a sclerotium is formed. No seed is produced by the infected floret.

Another fungus (Cladosporum sp.) grows profusely on the "honey dew", covering parts of the inflorescence with its mycelium and spores, giving it a black, sooty appearance and is a very obvious characteristic of infection. "Honeydew" is also well-known on sorghum (Sorghum bicolor subsp. arundinaceum) and paspalum where it is respectively formed by Claviceps sorghi and Claviceps paspali.

\section{Morphology}

The morphology of the sexual phase of the life cycle has been fully described by Loveless (1967). When a sclerotium germinates, a stroma consisting of a stipe (stem) with capitulum (head) is formed. The capitulum is at the upper end of the stipe, very similar to a mushroom. This structure is, however, very small and inconspicuous. The stipe may be up to $6 \mathrm{~mm}$ long and the capitulum only $1 \mathrm{~mm}$ in diameter. When sectioned, the different perithecia are clearly seen embedded within the capitulum. Inside the perithecia are the spore-carrying sacs called the asci. These asci contain needle-shaped ascospores. The ascospores have several septa at which they may separate with each fragment having the ability to inflect a floret of the nut sedge host plant.
The conidia are small and narrowly elliptic. The asexual stage resulting in conidia has now also been cultured in vitro and fully described by Van der Linde (2003).

The presently known distribution of $C$. cyperi appears in Fig. 11. Despite the world-wide distribution of Cyperus esculentus and $C$. rotundus their infection with Claviceps cyperi has not been recorded outside South Africa.

It is a characteristic of Claviceps spp. that although the whole infected host plant may contain toxin, its sclerotia are the particularly dangerously toxic components of the fungus as they contain the highest concentration of toxins (in this particular case ergocryptine). Exposure of animals to the sclerotial (overwintering) phase must, therefore, be avoided.

\section{Discussion}

It took almost 2 months from the first visit and the tentative diagnosis of ergotism on this farm to confirm the diagnosis and to determine the origin of the intoxication. This was only made possible by a concerted team effort by veterinarians, mycologists, animal scientists, chemists and the farmer.

That there was a certain degree of luck involved in this relatively rapid confirmation of the diagnosis is clear from the analytical results reflected in Table 1. To make the silage green maize plants as well as any weeds present, were mechanically cut about $80 \mathrm{~mm}$ above ground level. The density of the weed infestation, including nut sedge, on the land varied considerably from area to area. Loads of freshly-cut material were uniformly spread over the entire length of a particular bunker in consecutive layers. Consequently, maize originating from different areas of the land contaminated with different degrees of weeds and ergotised nut sedge was, therefore, present and haphazardly distributed in the final ensiled product. The ergot alkaloid concentration, therefore, would be expected to vary considerably in the bunker. This explains the fact that silage varied in its toxicity or lack of it (Table 1).

It was indeed fortunate that the silage fed to the sheep in one of the groups in the prolactin determination experiment contained enough alkaloid to lower their serum prolactin levels. This was of cardinal significance in the determination of the origin of the ergot intoxication. The negative response of the group receiving the silage-containing TMR is probably due to the dilution effect of the other constituents. 


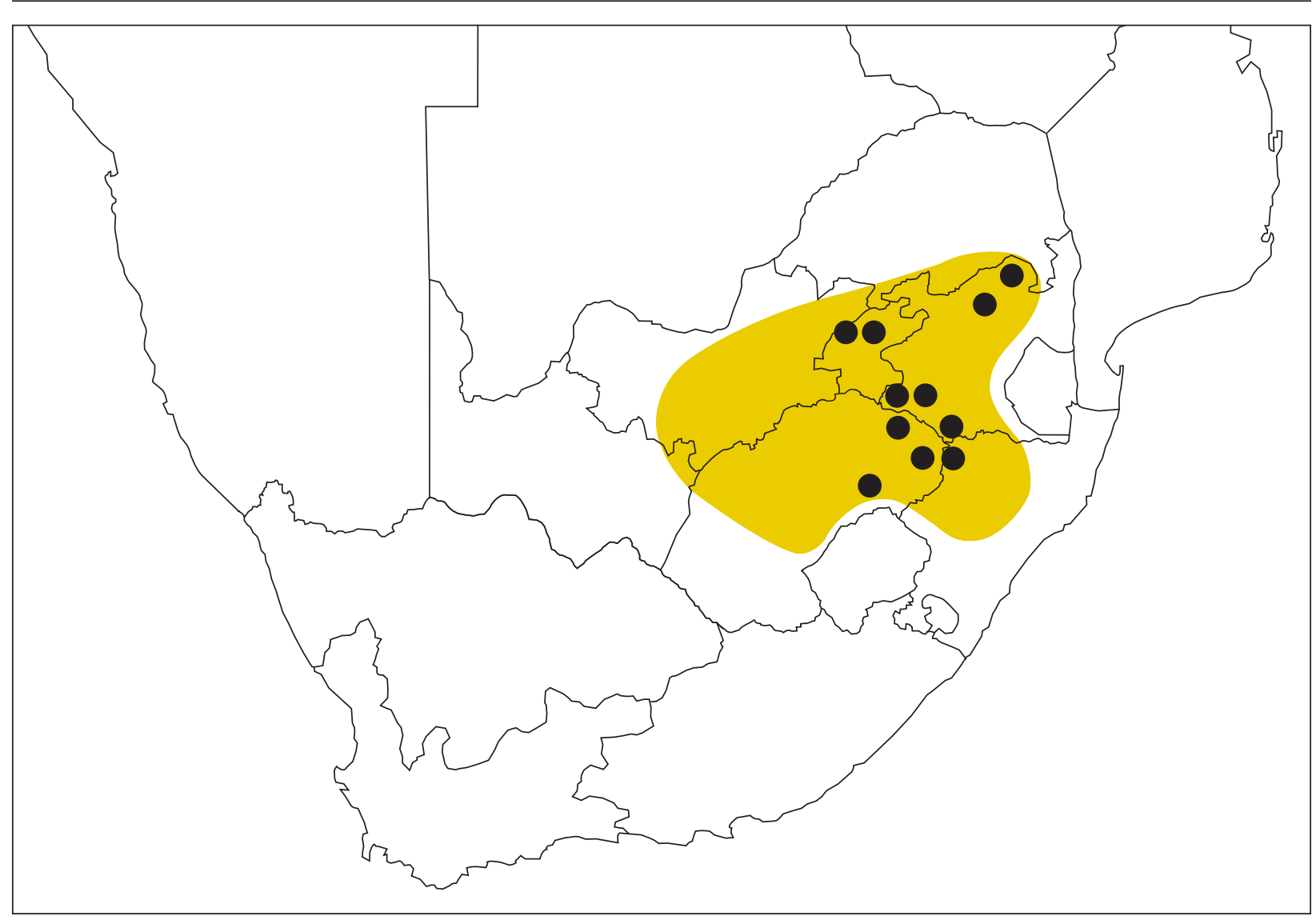

FIG. 11 The distribution of Claviceps cyperi in relation to the main maize producing area of South Africa

The apparent illogical finding that an unsifted teff seed sample was positive for ergocryptine could have been a serious "red herring" in the determination of the diagnosis at that stage of the investigation. This finding is, however, consistent with the fact that teff is an annual and, therefore, lands on which it is grown are as prone as maize lands to nut sedge infestation and thus to ergot contamination. The third outbreak investigated (vide infra) was undoubtedly due to nut sedge contaminated teff hay.

The rather slow recovery and return of milk yield and degree of infertility experienced in the cows of this particular herd (Fig. 3) can probably be ascribed to the prolonged exposure of more than 2 months to the alkaloids.

\section{SECOND OUTBREAK}

This outbreak of Claviceps cyperi ergotism occurred on a well-established and managed dairy farm near Memel which was visited on 11 February 1997. There were 150 Holstein cows in production and
317 animals in toto. Milk production was $10 \%$ above the country's average.

Typical summer syndrome with $70 \%$ of cows being affected, occurred. They manifested hyper pyrexia (once even breaking through an electric fence to get to a small stream), dyspnoea and polypnoea (which prompted testing and treatment for infectious bovine rhinotraecheitis and inoculation for bovine viral diarrhoea). A concomitant drop in milk production, was also experienced on two occasions, the first in August 1996 and the second in January 1997. The first had occurred when maize silage from a specific bunker made the previous year was fed to them. Clinical signs abated on cessation of its use. The second commenced when this silage was again used as feed, milk production decreasing from 2750

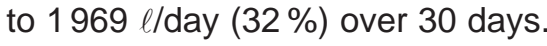

As had occurred in the first outbreak, seasonal late rains had resulted in making the lands inaccessible for early cutting of maize for ensiling. The farmer and his attending veterinarian had recognised the association of the syndrome with the silage and the farmer had ceased feeding it just prior to our visit. 
During the outbreak the cows received a TMR consisting of the following:

$5 \mathrm{~kg}$ silage (dry matter base, wet $15 \mathrm{~kg}$ )

$2 \mathrm{~kg}$ cotton seed

$4 \mathrm{~kg}$ dry lucerne

2-3 kg E. curvula hay

$11 \mathrm{~kg}$ of a commercial dairy meal.

On withdrawal of the silage the clinical signs had abated. Milk production had increased dramatically after 1 month and had returned to almost normal after 2 months. Two cows had, however, suffered from necrosis and eventual loss of the tips of their tails. More than normal problems with infertility in general were still being experienced. The hair coats of many animals had a definite reddish tinge.

\section{Specimens}

As in the first outbreak ten cows were bled for routine clinical haematological examination and specimens of the dairy meal and lucerne (brought-in feeds) and the locally produced hay and silage, were collected for chemical analysis. Extracts of the latter specimens were forwarded to the University of Missouri for examination for ergot alkaloids.

\section{Results}

Clinical pathology

As experienced in the first outbreak the haematological examinations revealed no remarkable deviations from normal.

\section{Chemical analyses}

The analyses for ergot alkaloids performed on extracts of the maize silage, E. curvula hay, dairy concentrate, cotton seed and lucerne forwarded to the University of Missouri, revealed that only the maize silage contained the alkaloids as is reflected in Table 4.

\section{Discussion}

A diagnosis of ergotism was evident and the syndrome was clearly associated with the feeding of

TABLE 4 Ergot alkaloid level of maize silage in the second outbreak

\begin{tabular}{|l|l|}
\hline Sample & Ergot alkaloid analysis \\
\hline Maize silage & $\begin{array}{l}680 \text { ppb ergocryptine } \\
295 \text { ppb ergocornine }\end{array}$ \\
\hline
\end{tabular}

the silage made in 1996. What was extraordinary in this case was that in the analyses for ergot alkaloids, apart from ergocryptine in the silage, an HPLC peak corresponding to ergocornine was evident, a finding that did not occur at the first (vide supra) and third outbreaks (vide infra).

On a subsequent visit, 1 month later, ergotised nut sedge was found to be abundant in the maize lands and actual sclerotia in the silage could be demonstrated with ease to the farmer by taking a handful of silage from the face of the bunker and spreading it on a white background.

This was the only farm where necrosis of the tail tips occurred in some of the cows.

The relatively rapid return of the cows to pre-exposure status can probably be ascribed to the short exposure period to the toxic silage.

\section{THIRD OUTBREAK}

This occurred from January to March 1997 in a mixed herd of milk cows comprising 120 Holsteins and ten Jerseys. Signs of heat stress were observed in the Holsteins (but not the Jerseys) which consisted of dyspnoea, polypnoea and salivation which were particularly evident after minor exercise. Attempts to cool off by lying in muddy pools and even in the drinking trough were also manifested. A drop in milk production of $14 \%$ in January, $26 \%$ in February and $18 \%$ in March was also experienced. A reddish tinge to the black hair of some of the Holsteins was evident.

The problem had followed a change in ration in late November 1996 when the ration was made up as follows:

$550 \mathrm{~kg}$ of self mixed concentrate

$150 \mathrm{~kg}$ E. curvula hay

$100 \mathrm{~kg}$ teff hay

$200 \mathrm{~kg}$ dried maize silage.

When silage was no longer available it was replaced in the ration by:

$50 \mathrm{~kg}$ gluten

$50 \mathrm{~kg}$ molasses.

The cows also had access to E. curvula and Digitaria eriantha pastures.

In December 1996 the ration was changed to:

$550 \mathrm{~kg}$ of the concentrate

$250 \mathrm{~kg}$ of teff hay. 
In addition to the two grass pastures, the cows also had access to feed sorghum grazing.

The basic change was that the teff concentration in the ration had changed from $10-31 \%$ and within 3 weeks the clinical sign of summer syndrome had set in. The farmer had suspected the teff and on its withdrawal the clinical signs gradually abated and milk production returned to normal.

Blood was collected for clinical pathological examination from ten of the most severely affected cows.

Extracts of feed specimens, as reflected in Table 5, were submitted to the Universitry of Missouri for ergot alkaloid determination.

Examination of the large round bales of teff hay which was incriminated, revealed that it was severely contaminated with Claviceps cyperi-infected Cyperus esculentus. Numerous sclerotia were present. The maize fields and feed sorghum and teff lands were all infested with heavily ergotised nut sedge. The land on which E. curvula was growing appeared to be free of it.

\section{Results of investigations}

\section{Clinical pathology}

As in the other two outbreaks this revealed no obvious deviations from the normal.

\section{Chemical analyses}

Extracts of milled teff hay, E. curvula hay, dried feed sorghum hay and dairy concentrate revealed that only the teff and E. curvula hay contained appreciable quantities of ergot alkaloids as summarised in Table 5.

\section{Discussion}

Just like maize, teff is an annual crop and, consequently, prone to nut-sedge weed infestation. If such nut sedge is, in addition, ergotised and the teff is cut when the nut sedge is seeding and the $C$. cyperi forming sclerotia for overwintering, it may present an ergot alkaloid concentration which may be problematic in stock. In this particular instance it is clear

TABLE 5 Ergopeptine levels of feed in the third outbreak

\begin{tabular}{|l|l|}
\hline Sample & Ergot alkaloid analysis \\
\hline Milled teff hay & 1200 ppb ergocryptine \\
Eragrostis curvula hay & 80 ppb ergocryptine \\
\hline
\end{tabular}

that this feed component was responsible for the outbreak.

On inspection this particular farm also had severely ergotised nut sedge infestation in all annual crops. Even the E. curvula, which is a perennial grass and thus not prone to infestation after the first year and which appeared to be free of the weed, contained ergocryptine at a level of $80 \mathrm{ppb}$.

\section{GENERAL DISCUSSION}

Although $C$. cyperi was first described by Loveless as long ago as 1967 (Loveless 1967) it was not known to be toxic until the investigation described here. Nut sedges, particularly $C$. esculentus and in South Africa to a lesser extent $C$. rotundus (C. Archer, National Botanical Institute, Pretoria, personal communication 2001), are troublesome weeds which occur in cultivated lands on which annual crops are grown and any feed contaminated with them, when ergotised, are potentially toxic. Both species of nut sedge have a world-wide distribution but to date infection with $C$. cyperi has only been described in South Africa. The infection is not very conspicuous as the sclerotia are very small and, consequently, the infection might have been missed elsewhere. An important indicator of possible ergot infection is a black, sooty Cladosporum infection of ripening nut sedge seed heads which precedes the appearance of the Claviceps sclerotia.

A novel finding of these outbreaks of ergotism was that $\alpha$-ergocryptine (Fig. 1), chemically confirmed by MS/MS, was the dominant alkaloid produced by C. cyperi. This alkaloid is usually a minor component of the alkaloids produced by Claviceps purpureum and Neotyphodium coenophialum. In the second outbreak a strong peak corresponding to ergocornine was detected in the silage but unfortunately the identity was not confirmed by MS/MS.

The fact that several specimens of silage from the first outbreak submitted for chemical analysis were negative for ergopeptine alkaloids can be ascribed to various factors such as an uneven distribution of ergotised $C$. esculentus on the maize lands with a consequent uneven distribution in the silage bunker. Furthermore, silage was dried on cement floors before despatch for analysis or extraction of ergopeptine alkaloid and at the outset particular care to pick up the fine material (possibly containing more sclerotia than the rest) and including this in the final specimen, was not taken. This might have resulted in false negative or low alkaloid levels. The finding 
that sclerotia recovered from silage where the alkaloids had been leaching out of them for months, still contained 36500 ppb ergocryptine, supports this assumption (Table 3). The sheep prolactin test, where the animals were fed silage as it came from the bunker for 11 days only, showed up the silage as the culprit and was an important indicator of the source. In retrospect, the success of the experiment was probably rather fortunate.

The causative fungus has undoubtedly been present in South Africa for many years. Maize silage and teff have always constituted significant components of stock feed and it can only be speculated whether the syndrome in cattle fed these feedstuffs has or has not previously occurred. If it has, then a specific aetiological diagnosis was not made and reported, nor was its significance realized. The exceptionally high intake of infected silage by the cows during the first outbreak, the very high concentration of alkaloids in the silage in the second outbreak and in the teff at the third outbreak, certainly contributed to the manifestation of the syndrome.

Efforts should be directed at minimising ergot contamination of stock feed as the pathological effects of these alkaloids are, as with all poisons, dose dependant. In the years subsequent to the investigation reported here, the problem has been recognised by veterinarians at an early stage, i.e. as soon as milk production decreases and early clinical signs of summer syndrome appear. On withdrawal of the contaminated feed from the animals the signs abate. There is, however, reason for concern as it is possible that exposure of stock to lower levels of ergot alkaloids does not manifest as typical summer syndrome and might result in undetected lowered milk production, fertility and production.

Deep cultivation of lands (versus the minimum tillage concept currently in use) will result in burying ripe sclerotia and will therefore reduce infection of the florets of nut sedge the following season. Maize growing on patchy areas in lands where heavy infestation of ripe nut sedge seeds occur, should not be used for silage production. Hand weeding such areas before the maize is cut can be considered. Another preventative strategy is to cut the maize plants at a higher level than the nut sedge heads-this has been used with success.

The herbicide halosulfuron ("Servien", Novartis) is expensive but is registered for post emergent control of Cyperus spp. in maize lands (Grobler et al. 2000). It impedes the development of floret and seed formation of nut sedge (and, consequently, ergot production) and can, therefore, be used selectively prior to the cutting of maize plants for ensiling to ensure that ripe, seeding nut sedge with its concomitant ergot contamination is not included in the final product.

Halosulfuron is not registered for use in teff lands but in commercial enterprises in which seed of $E$. tef is produced and it is most difficult to separate from that of teff. It is used with success in conjunction with 2.4-D to control annual weeds. However, when teff hay is produced for commercial purposes, use of such weedicide adds ca R 50/ton to the cost of production and the disadvantage of the presence of $C$. cyperi ergots in the last cutting of hay (when ergot formation is maximal) must be weighed up against the expense. Teff is used particularly for the feeding of equids and in the case of breeding mares (which are particularly susceptible to ergot poisoning [Cheek 1998]) this extra expense will certainly be justified. Contaminated teff should only be fed to stock after careful evaluation of the risk/benefit ratio.

\section{ACKNOWLEDGEMENTS}

Assistance from the following instances and individuals is greatly appreciated:

- The Toxinology \& Food Safety Research Group, Ruakura Research Centre, Hamilton, New Zealand for ELISA exclusion of endophytes and related toxins from the hay grasses

- Frank Ross of the United States Department of Animal and Plant Health Inspection Service for the tandem mass (MS-MS) confirmation of ergocryptine

- Meadows Cape, and in particular Mr Y. Geyer, for the initial exclusion of the ergot alkaloids in the HPC of the first outbreak and for finding the unsifted teff seed specimen from this farm positive for ergocryptine

- Dr Moira Bode of the OVI for preparing the alkaloid extracts when APHIS restrictions stopped the introduction of specimens to the USA

- Dr Trushke Gerdes of the Section of Virology of the OVI for bringing the second outbreak (from which she was examining specimens for suspected respiratory virus infection) to our attention

- Mr J.P. van Zyl, ARC-Animal Improvement Institute, Irene for expert statistical analysis and interpretation of the PRL results 
- Dr D.J. Schneider of Stellenbosch and Prof. T.S. Kellerman of the OVI for continued encouragement, advice and positive criticism

- Prof. R.C. Tustin for time-consuming, meticulous checking and positive criticism of and extensive changes to the manuscript.

\section{REFERENCES}

ASCOLI, M. \& SEGALOFF, L. 1996. Adenohypophyseal hormones and their hypothalamic releasing factors, in Goodman \& Gilman's the pharmacologic basis of therapeutics, edited by J.G. Hardman, L.E. Limbird, P.B. Molindorff, P.W. Rudden \& A.G. Gilman, $9^{\text {th }}$ ed. New York: McGraw-Hill.

BACON, C.W., LYONS, P.C., PORTER, J.K. \& ROBBINS, J.D. 1986. Ergot toxicity from endophyte-infected grasses: A review. Agronomy Journal, 78:106-116.

BOTHA, C.J., NAUDÉ, T.W., MOROE, M.L. \& ROTTINGHAUS, G.E. 2004. Gangrenous ergotism in cattle grazing fescue (Festuca elatior L.) in South Africa. Journal of the South African Veterinary Association, 75:45-48.

CHEEK, P.R. 1998. Natural toxicants in feeds, forages, and poisonous plants, $2^{\text {nd }}$ ed. Danville, Illinois: Interstate Publishers.

DOIDGE, E.M. 1950. The South African fungi and lichens up to 1945. Bothalia, 5:1-1094.

FUENTES, S.F., DE LOURDES DE LA ISLA, M., ULLSTRUP, A.J. \& RODERIQUEZ, A.E. 1964. Claviceps gigantea, a new pathogen of maize in Mexico. Phytopatologia, 34:379381.

FUCIKOVSKY, L. \& MORENO, M. 1971. Distribution of Claviceps gigantea and its per cent attack on two lines of corn in the state of Mexico. Plant Disease Reporter, 55: 231-233.

GARNER, G.B., ROTTINGHAUS, G.E., CORNELL, C.N. \& TESTERECI, H. 1993. Chemistry of compounds associated with endophyte/grass interaction: ergovaline- and ergopeptinerelated alkaloids. Agriculture, Ecosystems and Environment, 44:65-80.

GARTHWAITE, I. 1997. Cellular and molecular techniques for characterising Acremonium/grass interactions, edited by C. Bacon \& N.S. Hill. Proceedings of the $3^{\text {rd International Neo- }}$ typhodium/Grass Interaction Symposium. New York: Plenum Press: $361-376$.

GARTHWAITE, I., SPROSEN, J., BRIGGS, L., COLLIN, R. \& TOWERS, N. 1994. Food quality on the farm: Immunological detection of mycotoxins in New Zealand pastoral agriculture. Food and Agricultural Immunology, 6:123-129.

GROBLER, H., VERMEULEN, J.B. \& VAN ZYL, K. 2000. A guide to the use of herbicides, $9^{\text {th }}$ ed. Pretoria: National Department of Agriculture.

HOFFMAN, B.B. \& LEFKOVITZ, R.T. 1996. Catecholamines, sympathomimetic drugs and adreneric receptor antagonists, in Goodman \& Gilman's the pharmacologic basis of therapeutics, $9^{\text {th }}$ ed., edited by J.G. Hardman, L.E. Limbird, P.B.
Molindorff, P.W. Rudden \& A.G. Gilman. New York: McGraw-Hill.

HOLM, L.G., PLUCKNETT, D.L., PANCHO, J.V. \& HERBERGER, J.T. 1977. The world's worst weeds: distribution and biology. Honolulu: University Press of Hawaii.

HUNTER, W.M. \& GREENWOOD, F.C. 1964. A radio-immunoelectrophoretic assay for human growth hormone. Biochemical Journal, 91:43-56.

LOVELESS, A.R. 1967. A new species of Claviceps on Cyperaceae. Transactions of the British Mycological Society, 50: 19-22.

OSWEILER, G.D., CARSON, G.D., BUCK, W.B. \& VAN GELDER, G.A. 1985. Clinical and diagnostic veterinary toxicology, $3^{\text {rd }}$ ed. lowa: Kendal/Hunt.

PEROUTKA, S.J. 1996. Drugs effective in the therapy of migraine, in Goodman \& Gilman's the pharmacologic basis of therapeutics, $9^{\text {th }}$ ed., edited by J.G. Hardman, L.E. Limbird, P.B. Molindorff, P.W. Rudden \& A.G. Gilman. New York: McGraw-Hill.

PLATTNER, R.D., YATES, S.G. \& PORTER, J.K.1983. Quadrapole mass spectrometry/mass spectrometry of ergot cyclol alkaloids. Journal of Agriculture and Food Chemistry, 65: 785-789.

PONS, W.A. \& HOFFPAUIAR, C.L. 1957. Determination of free and total gossypol in mixed feed containing cotton seed meals. Association of Official Agricultural Chemists 44:1068- 1080 .

RETIEF, E. \& HERMAN, P.J.J. 1997. Strelitzia 6. Plants of the northern provinces of South Africa: Keys and diagnostic characters. Pretoria: National Botanical Institute.

RODBARD, D. \& FRAZIER, G.R. 1975. Statistical analysis of radioligand assay data. Methods in Enzymology, 37:3-22.

ROTTINGHAUS, G.E., SCHULTZ, L.M., ROSS, P.F. \& HILL, N.S. 1993. An HPLC technique for the determination of ergot contamination in ground feedstuffs. Journal of Veterinary Diagnostic Investigation, 5:242-247.

SAHA, D.C., JACKSON, M.A. \& JOHNSON-CICALESE, J.M. 1988. A rapid staining method for detection of endophytic fungi in turf and forage grasses. Phytopathology, 78:237239.

SCHNEIDER, D.J., MILES, C.C., GARTHWAITE, I., VAN HALDEREN, A., WESSELS, J.C. \& LATEGAN, H.J. 1996. First report of field outbreaks of ergot-alkaloid toxicity in South Africa. Onderstepoort Journal of Veterinary Research, 63: 97-108.

SCOTT, P.M., LOMBAERT, G.A., PELLAERS, P., BACHLER, S. \& LAPPI, J. 1992. Ergot alkaloids in grain foods sold in Canada. Journal of the Association of Official Analytical Chemists International, 75 (5):773-779.

TULASNE, L.R. 1853. Mémoire sur l'ergot des Glumacées. Annales des Sciences naturelles (Botanique), séries 3, 20: 5-56.

VAN DER LINDE, E.J. 2003. Ergot of nutsedge in South Africa. Ph.D. thesis, University of Pretoria.

VAN ZYL, J.P. 1988. Prolaktien en produksie-eienskappe van melkbeeste. M.Sc. (Agric.) thesis, University of the Orange Free State. 